\title{
Eoan - Our Story: Treading new methodological paths in music historiography
}

\author{
Hilde Roos*
}

\begin{abstract}
This article focuses on the use of innovative methodologies in the writing of Western classical music history as illustrated in the publication of the book Eoan - Our Story (2013). The primary methods used in this book are oral history and community interaction and I argue that the use of these methodologies have become possible due to recent developments in the discipline of musicology. I therefore begin with a brief exposition of some key changes in the discipline over the past few decades and highlight the triangular tension that underlies it: the autonomy of music, music in its social and cultural contexts and the loss of notion of "the objective fact" with its concomitant foregrounding of language and the position of the author. Eoan - Our Story recounts the experiences of an opera, dance and ballet company that operated as a so-called coloured arts organisation during the apartheid years in South Africa. Because this group found itself on the receiving end of dominant political and artistic discourses (pre- and post-1994), a democratised method was sought to allow for silenced voices to speak. The book was therefore put together by a committee comprising former Eoan members as well as academics. The challenges of "writing a book by committee" are numerous especially in an environment where the authority of the academic had to give way to other concerns. In my view however, these offset the creativity and innovative pathways these methodologies can bring to music historiography.
\end{abstract}

Keywords: Eoan Group; opera; music historiography; New Musicology; oral history; community interaction; Hobsbawm.

\section{Opsomming}

Hierdie artikel bespreek die gebruik van vernuwendes metodes vir die skryf van die geskiedenis van Westerse klassieke musiek in Suid-Afrika soos dit toegepas is in die publikasie Eoan-Our Story (2013). Mondelingegeskiedenis en gemeenskapsinteraksie

\footnotetext{
${ }^{*}$ Hilde Roos is a postdoctoral fellow at the University of South Africa. She has published in Acta Academica, The South African Theatre Journal, Muziki and Acta Musicologica. She is coeditor of the oral history publication, Eoan History Project, Eoan - Our Story (Fourthwall Books, Johannesburg, 2013).
}

\section{How to cite this article:}

H. Roos, "Eoan - Our Story: Treading new methodological paths in music historiography", Historia 60, 2, November 2015, pp 185-200. http://dx.doi.org/10.17159/2309-8392/2015/v60n2a9

(C) 2015. The Author(s). Published under a Creative Commons Attribution License. 
is die primêre metodes wat gebruik is en ek voer aan dat dit moontlik geword het as gevolg van onlangse ontwikkelinge in die dissipline van musiekwetenskap. Die artikel begin met ' $n$ kort uiteensetting van hierdie veranderinge van die afgelope paar dekades en belig die drieledige spanningsveld wat dit onderlê, naamlik die outonomie van musiek, musiek in sy kulturele en sosiale kontekste en die verlies van die idee van "die objektiewe feit" wat die posisie van die skrywer/verteller en die gebruik van taal op die voorgrond plaas. Eoan - Our Story vertel die verhaal van 'n opera, drama en ballet geselskap wat tydens die apartheidsjare in Suid-Afrika as 'n sogenaamde kleurling organisasie gefunksioneer het. Omdat hierdie groep (voor en na 1994) deur heersende politieke en artistieke diskoerse benadeel is, is ' $n$ gedemokratiseerde metode gesoek wat voorheen stilgemaakte stemme ruimte gee om gehoor te word. Die boek is om daardie rede saamgestel deur ' $n$ komitee wat uit vorige lede van Eoan en akademici bestaan het. In 'n omgewing waar die outoriteit van die akademikus plek moes maak vir ander prioriteite was die uitdaginge van die skryf van 'n boek deur 'n kommitee soos hierdie veelvoudig. Ek voer aan dat die die kreatiewe en innoverende resultate van hierdie proses positief afweeg teen die uitdaginge.

Sleutelwoorde: Eoan Group; opera; musiekhistoriografie; New Musicology; mondelingegeskiedenis; gemeenskapsgeskiedenis, gemeenskapsinteraksie; Hobsbawm.

On 31 January 2013 the first book publication on the Eoan Group, South Africa's oldest amateur opera, ballet and theatre company, was celebrated in the Cape Town City Hall. The launch was the culmination of a five-year process during which a group of eight people from varying backgrounds came together in a (somewhat prolonged) attempt to document the extraordinary history of an arts organisation that existed throughout the apartheid years as a so-called coloured organisation. The group itself, or any interpretation of its history is, however, not the focus of this article - although a very short introduction is provided for the sake of context - but rather the methodology used to create this book. Eoan - Our Story makes use of the innovative methods of community interaction and oral history to create a space in music historiography for a community of classical music artists whose history has been silenced for many years, not only during apartheid, but also in the decades following the birth of democracy in South Africa. In my role of project manager and co-editor of this book, I have intimately experienced the challenges and intricacies of the application of these methods, but also witnessed the creative and surprising results of such an exercise. This article is therefore written as a methodological reflection on the way community interaction and oral history can be applied to South African classical music historiography.

In order to situate the book within the field of music historiography and trace the methodological roots of the publication, it is necessary to first take recent trends in music historiography and the larger field of musicology into consideration because these provided the space within which the methodology for the book was 
conceptualised. It was also with these considerations in the background that the process of the making of this book was able to run its course in an unfettered manner.

The past thirty years has seen much debate and change with regard to the methodologies employed in the discipline of musicology, and the field of methodology to this day remains an area of continued contestation and innovation. During much of the twentieth century the discourse within musicology was dominated by an approach that viewed the musical work as an autonomous and closed entity, worth studying for its own sake. In contrast to this, studies on music as a cultural product began gaining momentum with Joseph Kerman's (in)famous 1985 publication Contemplating Music, ${ }^{1}$ that debated the discipline's adherence to the hierarchy of music as autonomous and self-referential above the contexts that shape music. This debate has since made major inroads in the world of musicology and subsequently provided many innovative approaches and research outputs. In Anglo-American musicology, the "autonomy debate", as it came to be known, sparked a wave of research outputs in the 1980s and 1990s that prioritised contextual factors in analysis and historiography and established the disciplinary brand called New Musicology.

The primary philosophical and methodological traits of New Musicology have been discussed, debated and expounded upon by numerous writers including Lawrence Kramer, Susan McClary, Lydia Goehr, Gary Tomlinson, Nicholas Cook, Richard Taruskin and Suzanne Cusick (to name but a few) and the way this has changed the discipline is today well known in the academic fraternity. I will therefore not go into further discussion on this; suffice it to say that this trend's negative stance towards the methods of positivism and formalism in music studies continues to cause division amongst scholars and has even posited national disciplinary traditions on either side of the "new line". ${ }^{2}$ Much of the research output has since gained the status of canonised literature, sparking yet another debate alleging the hegemony of New Musicology. Music as an autonomous entity has even seen a slight comeback with contributions by scholars as such as David Clark's discussion of the autonomy

\footnotetext{
${ }^{1}$ J. Kerman, Contemplating Music (Harvard University Press, Cambridge: MA, 1985). This title has been used for the American edition of this publication. The British edition is entitled: Musicology.

2 E. Rieger, "Crossing Boundaries? The Relationship between the Anglo-American and AustroGerman Worlds of Musicology", Musicology Australia, 22, 1999, pp 81-88. With the exception of Christopher Ballantine's writings, see for instance his Music and its Social Meanings (1984), New Musicology gained a foothold in South African classical music scholarship from 2000 onwards, while some local scholars to this day reject the development altogether. Reflections on how New Musicology has influenced the discipline methodologically can be found in comments scattered among articles by scholars working in the tradition, including writers such as Martina Viljoen, Christopher Ballantine, Zelda Potgieter, Christine Lucia, Stephanus Muller, Carina Venter and Mareli Stolp, yet none of them specifically comment on more recent methodological developments in local music historiography. Hence the initiative to write this article.
} 
principle in popular and jazz music in his article Musical Autonomy Revisited ${ }^{3}$ and music educationalist Lucy Green's plea for the return thereof in Musical Meaning and Social Reproduction: A Case for Retrieving Autonomy. ${ }^{4}$

Apart from the establishment of New Musicology, the discipline of musicology (and for that matter much else in academia and the rest of the world) has been confronted by the emergence of post-modernist relativism that questions the idea of objectivity and existence of facts. Historians have debated this issue at length with writers arguing for and against a notion that seems to threaten the very principles upon which historiography as a discipline is based. Eric Hobsbawm formulates the problem as follows:

It has become fashionable in recent decades, [...] to deny that objective reality is accessible, since what we call "facts" exist only as a function of prior concepts and problems formulated in terms of these. The past we study is only a construct of our minds. ${ }^{5}$

Although Hobsbawm and many other historians do not necessarily support this train of thought, ${ }^{6}$ relativism has come to stay and its pervasive influence can be seen in the dubitation of the authority of what was traditionally accepted as fact. In the humanities at least, this resulted in the heightened authority of language as written or spoken text in favour of the notion of the objective fact.7 In other words, the way in which things are formulated, as Hobsbawm states above, is seen as "the truth" (even if very fleetingly and subjectively experienced) with a concomitant foregrounding of the author as protagonist, a trend its detractors like to describe as "the linguistic turn" that changed history into "another branch of literature". ${ }^{8}$

These developments have had a major influence on the writing of music history. In his essay The Historiography of Music: Issues Past and Present, Leo Treitler reveals his scepticism towards the ways in which the autonomy debate as well as the elevation of language and the author has affected music historiography. He writes that "the historical object can be so densely contextualized as to be camouflaged into invisibility; [or] it can disappear in the brilliant glare of idiosyncratic virtuoso writing". ${ }^{9}$ Admittedly so, a number of present day scholars in musicology, Richard Taruskin for one, have built their reputations and followings from vast and in-depth knowledge as well as virtuoso and entertaining writing skills. However, despite

${ }^{3}$ D. Clark, "Musical Autonomy Revisited", in M. Clayton, T. Herbert and R. Middleton (eds), The Cultural Study of Music, a Critical Introduction (Routledge, New York and London, 2003), pp 159-170.

${ }^{4}$ L. Green, "Musical Meaning and Social Reproduction: A Case for Retrieving Autonomy", Educational Philosophy and Theory, 37, 1, 2005, pp 77-92.

${ }^{5}$ E. Hobsbawm, On History (Weidenfeld \& Nicholson, London, 1997), p viii.

${ }^{6}$ Hobsbawm goes on to state that "without the distinction between what is and what is not, there can be no history", see p viii.

7 R.J. Evans, In Defence of History (Granta, London, 1997), pp 75-102.

${ }^{8}$ Evans, In Defence of History, pp 75-103.

${ }^{9}$ L. Treitler, "The Historiography of Music: Issues Past and Present", in N. Cook and M. Everist (eds), Rethinking Music (Oxford University Press, Oxford, 1999), pp 356-377. 
Treitler's fingering of the "dangers" of these new trends and his underwriting of the idea of music as object, the triangular tension that plays out in current music historiography are clearly set out: music (as autonomous text), its social, cultural and political contexts and the language through which it is transposed to the reader, are the considerations that nowadays need to be taken into account when one attempts to write music history. The foregrounding of the social and political context of music making, the focus on the voice of the author and the legitimacy of multiple representations and interpretations of a given historical experience in music historiography can however do good service. Such concerns have levelled the playing fields for the writing of histories of music that would not have found their way into an environment where formalism and positivism continue to hold sway. Such concerns have indeed formed the methodological foundations of the creation of Eoan - Our Story.

In South African historiography in general, oral history as a method and the documenting of social histories via community engagement have been productively employed since the 1970s and abroad it has been in use since the 1940s. Against the backdrop of histories that were marginalised or repressed during apartheid, institutions such as the Centre for Popular Memory (CPM) at the University of Cape Town; ${ }^{10}$ the Sinomlando Centre at the University of KwaZulu-Natal; ${ }^{11}$ the History Workshop at the Wits University; ${ }^{12}$ and many more, have done much to educate students and communities in oral history research, theory and representation. The practise and theory of oral history in South Africa and abroad have been written on extensively. ${ }^{13}$

At the heart of oral history as a method lies the challenge toward the authority and power of the written archive as "truth". Sean Field argues that Portelli's 1994 conceptualisation of the method that,

\begin{abstract}
approaches truth as much when it departs from "facts" as when it records them carefully, because the errors and even the lies reveal, under scrutiny, the creative processes of memory, imagination, symbolism and interpretation that endow events with cultural significance... ${ }^{14}$
\end{abstract}

This has been accepted by scholars worldwide and has validated oral history as method in itself instead of a way of "filling in the gaps of the archive". 15 The Truth and Reconciliation Commission (TRC) has also prompted a wide range of oral histories that illustrate the method's capacity to document and mediate painful pasts,

\footnotetext{
${ }^{10}$ See www.cpm.uct.ac.za CPM is now defunct.

${ }^{11}$ See http://sinomlando.ukzn.ac.za/

12 See http://www.wits.ac.za/historyworkshop

${ }^{13} \mathrm{~S}$. Field, "Turning up the Volume: Dialogues about Memory Create Oral Histories", South African Historical Journal, 60, 2, 2008, p 181.

${ }^{14}$ A. Portelli, The Text and the Voice, Writing, Speaking and Democracy in American Literature (Colombia University Press, New York, 1994), p 53, as quoted in Field, "Turning up the Volume".

${ }^{15}$ Field, "Turning up the Volume", p 176.
} 
yet Field warns against idealising oral histories as "the golden road to alternative or popular historical truth[s]", arguing that it opens up opportunities for the exploration of new insights in the way varying remembrances intersect with each other. ${ }^{16}$

Before we dive into the process of the making of Eoan - Our Story, some "factual" background is provided on the Eoan Group; this in order to give the necessary context for the methodological choices. The Eoan Group was founded in District Six in 1933 as a cultural and welfare organisation for the so-called coloured community of Cape Town, performing opera, ballet and drama throughout the apartheid years. During the early years of the group's existence their activities focused on elocution, drama, physical education and ballet rather than opera. In 1943, Joseph Manca, an accountant of Italian descent with a passion for opera, took over the group's choir and in the course of the following 13 years, he developed the choir into an amateur opera company. In March 1956, the Eoan Group presented Cape Town audiences with a full-scale production of Verdi's La Traviata, sung in Italian and performed in traditional Italian style. This production was part of a bigger Arts Festival that included a range of choral, ballet and drama productions, all staged in the Cape Town City Hall in the course of that year. District Six was notorious for its poor living conditions where inhabitants had little access to education or well-paid jobs and unemployment and poverty were rife. Despite these adverse circumstances, Eoan's first opera production proved most successful and in the twenty years following this performance, its name became synonymous with opera production in Cape Town. ${ }^{17}$

From 1956 to 1975 the Eoan Group was an active part of the classical music scene of Cape Town and was popular with the opera loving public. During these years the group presented eleven opera seasons; toured the country twice; launched a Second Arts Festival in 1962; premièred an indigenous ballet (The Square by Stanley Glasser); and had the opportunity to tour abroad in 1975. Its history bears testimony to exceptional talent and the will to overcome. Many singers (including various principal singers) could not read music notation, singers were unfamiliar with the Italian language and throughout these years, none of their singers, dancers, trainers, producers or other support staff were paid professional fees. In fact, all activities took place after working hours and over weekends. As a result of South Africa's racial policies during apartheid, however, the group was not allowed to perform with white opera and ballet companies and never gained access to first-class education opportunities. Another chronic problem was that of funding: sustaining an ever growing amateur opera company was a huge financial burden and for most of this time, the group accepted funding from the apartheid government in order to be able to stage its productions. Small as these amounts may have been compared to subsidies received by white opera companies, it caused the group to become

\footnotetext{
${ }^{16}$ Field, "Turning up the Volume", p 177.

${ }^{17}$ H. Roos, “Opera Production in the Western Cape: Strategies towards Indigenization”, DPhil thesis, Stellenbosch University, 2010, chapter 2.
} 
politically compromised and by the late 1970 s the coloured community viewed the Eoan Group as supporters of the apartheid government - and withdrew its support. ${ }^{18}$

By 1975, when the group presented its last opera season, its repertoire included eleven operas and three musicals: Verdi's La Traviata, Rigoletto and Il Trovatore; Puccini's Madame Butterfly and La Bohème; Strauss's Die Fledermaus; Bizet's Carmen; Donizetti's L'Elisir D'Amore; Rossini's Barber of Seville; Leoncavallo's I Pagliacci; and Mascagni's Cavalleria Rusticana. In the late 1960s, the group premièred the South African productions of three Hammerstein musicals: Oklahoma!, South Pacific and Carmen Jones. However, with Manca's resignation from the group in 1977, the curtain came down on an era of prolific opera production. ${ }^{19}$ The group nevertheless continued its activities, albeit on a much smaller scale and it currently functions as a ballet school. In 2013 the Eoan Group celebrated the 80th anniversary of its founding.

Indicative of the difficulties of dealing with a politically compromised past, the extraordinary history of this group however remained under wraps until late in 2006. ${ }^{20}$ The head of the Documentation Centre for Music (DOMUS), Prof. Stephanus Muller, describes how this history was re-discovered in his introduction to the book:

The story of this book starts with a telephone call on 14 November 2006 to Ms Santie de Jongh, the archivist of the Documentation Centre for Music (DOMUS) at Stellenbosch University's Department of Music. The enquiry about Eoan documents by Mr Charles de Long, a former member of the Eoan Group now living in Australia, and Santie's diligent pursuit of information to help him, set in motion, over the course of the next twelve months, a series of visits and meetings between the Department of Music and the Eoan Board (based at the Joseph Stone Theatre in Athlone, Cape Town). ${ }^{21}$

After a protracted period of negotiation between the current leadership of the group, the Eoan Board, under direction of Shafiek Rajap and DOMUS at Stellenbosch University, the Eoan Group Archive was transferred from the Joseph Stone Theatre in Athlone on the Cape Flats to DOMUS in February 2008. During the negotiations a contract was drawn up by the Eoan Board, DOMUS and Stellenbosch University's legal team to facilitate the transfer. It was a contract that incorporated two significant conditions. Firstly, the archive was not donated to DOMUS, it was loaned to DOMUS in terms of a 99 year loan agreement, indicating that the Eoan Board decided not to relinquish ownership of the archive to the university. In the context of Stellenbosch University's political standing during apartheid and its exclusion of coloureds from its campus for many years, this is understandable, and from the onset, those involved

\footnotetext{
${ }^{18}$ Roos, "Opera Production in the Western Cape", chapter 2.

${ }^{19}$ Roos, "Opera Production in the Western Cape", chapter 2.

${ }^{20}$ I discuss the way in which the history of the group has been dealt with after the cessation of opera activities in 1980, until the discovery of the archive. See H. Roos, "Remembering to Forget the Eoan Group": The Legacy of an Opera Company from the Apartheid Era", South African Theatre Journal, 2006, 27, 1, pp 1-18.

${ }^{21}$ Eoan History Project, Eoan - Our Story, p xiv.
} 
with the archive and the making of this book were acutely aware of the fact that this material was an important part of coloured cultural heritage and one towards which the community felt a strong sense of ownership. Secondly, the contract stipulated that DOMUS was to publish a book on the history of the group. ${ }^{22}$

In the early stages of the making of the book, Muller came with two suggestions that were destined to influence the methodology as well as the content of the end product in a decisive manner. Firstly he suggested that the format of an oral history be used instead of a conventional history. A cursory investigation into the archive indicated that the story of the Eoan Group was that of artistic expression silenced by political concerns, not only during apartheid, but also after the political liberation of 1994. From the pages of the archive emerged a story of prolific opera production running concurrently with a narrative of political compromise that ultimately succeeded in silencing the voices of opera singers, choristers, actors and ballet dancers. ${ }^{23}$ Representative of this, the documentation on the group's history lay stowed away underneath the orchestra pit in the Joseph Stone Theatre for more reasons than just that of needing storage space. Since many of Eoan's former opera singers, dancers and actors were still alive when the archive came to DOMUS (they were aged between 60 and 90 at the time), the format of an oral history provided an ideal opportunity to engage with the Eoan community.

In his essay The Voice of the Past, Paul Thompson argues that all history writing depends on its social purpose, yet oral history has the potential to change the content and purpose of the discipline. ${ }^{24}$ It does this in a variety of ways, among others, by breaking down traditional barriers (i.e. between the academic and the interviewee) but most relevant to our situation, oral history, "can give back to the people who made and experienced history, through their own words, a central place [in history]". Peter Burke describes it as part of "la nouvelle histoire" where the traditional "view from above" that focuses on the deeds and views of great men is replaced by a "view from below" offering "the views of ordinary people and their experience of social change". ${ }^{25}$ This is not to say that the opera performances of Eoan are deemed lower in the hierarchy of "great deeds", but through oral history the experiences of ordinary people involved in an organisation such as Eoan, who performed opera in extraordinary circumstances, can be related to the reader through the medium of the every day.

Secondly, Muller suggested that this book could be created together with members of the Eoan community in contrast to the conventional academic enterprise of the single-authored monograph. This decision was based on various concerns. On

\footnotetext{
${ }^{22}$ See University of Stellenbosch (hereafter US), Documentation Centre for Music (hereafter DOMUS), Eoan Group Archive, "Memorandum of Agreement between Eoan and Stellenbosch University", dated 28 January 2008.

${ }^{23}$ Roos, "Remembering to Forget the Eoan Group", p 2.

${ }^{24}$ P. Thompson, "The Voice of the Past: Oral History", in R. Perks and A. Thomson (eds) The Oral History Reader (Routledge, London and New York, 2003), pp 25-31.

${ }^{25}$ P. Burke, New Perspectives on Historical Writing (Polity Press, Cambridge, 2001), pp 2-4.
} 
the one hand, Stellenbosch University has formally acknowledged that in order to serve as a relevant institution within the wider community of South Africa, it should actively engage with the community outside conventional academic borders. Accordingly, the university has established a division for community Interaction that initiates and manages partnerships with communities, thus facilitating cooperation and providing the means whereby both parties can actively partake in the discovery and production of knowledge in a reciprocal relationship. ${ }^{26}$ It is for this reason that the term "interaction" has been chosen, rather than "engagement" since the policy consciously seeks a two-way relationship ${ }^{27}$ where power is shared equally between scholars and the community. On the other hand the university also acknowledged that it has a responsibility to engage with the past in order to heal wounds caused by apartheid. It is in this spirit that the format of Eoan - Our Story as an oral history, compiled together with former members of the group, was created.

Lofty ideals aside, in practice this would imply that authorship would be a group effort and the concept of "making a book by committee" presented uncharted territory where control of the author had to be surrendered in favour of collective decision-making. I will now describe how this process unfolded and, at points where the format and content of the book were clearly influenced by the group decisions, highlight how the outcome of such decisions diverged from purely academic concerns.

Fundamental to the project was the establishment of a relationship between the Eoan community and the university. As mentioned before, historically, Stellenbosch University does not have the best of reputations with the coloured community, especially within the generation that bore the brunt of apartheid legislation. Our entire target group comprised individuals formerly shunned by our institution. Building this relationship also proved to be an ongoing process which continues to this day. We began by holding a series of meetings at venues where the group used to perform. On 1 October 2008 a meeting was held with the Eoan Board and important role players in the Eoan community in the Joseph Stone Theatre in Athlone. This was followed by a meeting with a larger group of former Eoan soloists, choir members, dancers and administrators in the District Six Museum in Cape Town. The purpose of these meetings was for us to come to know former members and spread the word amongst the community about our plans to produce a book together with them.

After advertising widely in provincial and local newspapers and on radio, a public meeting to discuss the book project was held on 9 November 2008. It was attended by about 25 people and had the main purpose of finding volunteers to participate in the book project. Four attendees volunteered to become involved. They were Bishop John Ulster (a retired pastor from the Moravian Church, born and bred

26 "Stellenbosch University Community Interaction Policy", 2009 at http://www.sun.ac.za/ english/ci/about/policy-documents, accessed 29 July 2014.

27 "Stellenbosch University Community Interaction Policy", para. 4.3. 
in District Six, and brother of the conductor Dan Ulster); Ronnie Samaai (a violin teacher in his seventies who runs his own music school and is the brother of one of Eoan's principal tenors, Gerald Samaai); Ruth Fourie (a retired nurse in her seventies and widow of Eoan's most famous baritone, Lionel Fourie); and Wayne Muller (then still a journalist at Die Burger whose interest in the book was triggered by his father's close friendship with Gerald Samaai). The DOMUS team consisted of Stephanus Muller (head of DOMUS); Santie de Jongh (DOMUS archivist); Christine Lucia (extraordinary professor in the Department of Music) and myself.

These eight people now formed the Eoan Group Book Committee. A few months later, Philip Swales (chairman of the Eoan Group Trust and former principal baritone of the group) also joined the Book Committee, while Bishop John Ulster resigned due to his already overextended commitments. By this time, I was appointed as the coordinator of what became known as the Eoan Group Book Project. My academic research interests (opera production in the Western Cape) and specifically my interest in the Eoan Group Archive meant that I was ideally placed to hold together a process that we knew was going to make substantial demands on time and logistics.

Even at this early stage, the process of discussion was being filmed by Aryan Kaganof, who had agreed to make a documentary film about the process of making the book. This development followed from the realisation that the process of making $a$ book on Eoan would be a fascinating contemporary process of how the South African past is negotiated, claimed, used, contested and eventually written by South Africans. The idea therefore took root not only to compile memories as an historical celebration of Eoan (the book), but reflexively also to document the engagements between role players and their attendant emotions as glimpses on the ways in which a painful past is mediated in the present. ${ }^{28}$

In early 2009 the book committee held a series of meetings in quick succession to kick start the process. At these meetings themes and ideas for the book were explored and it was during a meeting on 5 March 2009 that the first major collective decision was made that determined the structure of the book. It was decided to arrange questions for interviewees on the basis of a number of themes; in the end these themes became the chapters of the book. As a result the format of the book steered away from a chronology while simultaneously creating space for traumatic experiences to be related as much as celebratory ones. The following themes and related keywords shaped the interviews:

\footnotetext{
${ }^{28}$ Kaganof's film on this material, entitled "An Inconsolable Memory", was completed early in 2013. It premièred at the Encounters Film Festival in Cape Town in June and was also screened at the International Documentary Film Festival in Amsterdam in November 2013 where it was short-listed for the Feature Length Competition. The film has also been screened at national and international festivals in the course of 2014 when it played in Milan, Italy in May; Seoul in South Korea in August; and was also screened at the National Arts Festival in Grahamstown in July.
} 
1. Origins: the beginnings of the group; its leaders; opera production; the group branches; the group as social welfare organisation focusing on cultural "upliftment", serving the community and early religious convictions.

2. Body: "the dancer"; racial categorisation; inclusion/exclusion on the bases of race; the influence of legislation and separate amenities on day-to-day activities.

3. Structure: leadership; finances; administration; the Eoan Trust and the Eoan Board; managerial hierarchies within the group.

4. Work: livelihood; artists being in or out of work; rehearsals; performances; teaching others; training self; backstage activities; the building of sets and the sewing of costumes.

5. Play/On stage: productions; drama; great operatic disasters; successes; musicals; oratoria; opera; operetta; stardom; voice coaching and vocal roles; the orchestra; dance and ballet; the chorus; and operatic directing.

6. Place: venues for performances; rehearsals; admin spaces; artists' homes; going on tour; the destinations; accommodation during tours and going overseas.

7. Support: family; the community (all races); funding in general; government subsidies (municipal, provincial); and individuals who supported the group.

These themes allowed for a discussion on and beyond the music and aimed to illustrate how the activities of the group, including opera, ballet and drama, made a difference to ordinary people who were on the receiving end of a politically unjust system.

On the basis of these themes the committee then collectively compiled and arranged sets of questions to form the basis of the interviews. Structurally, this was important not only because it would facilitate a more focused collection of data, but also because the interviews were being conducted by a team of people (the committee members) whose backgrounds, interests and personal involvement with the interviewees and Eoan's history were vastly different. A consent form was prepared stating clearly that the purpose of the interviews was to "document the history and legacy of this group as a book, film documentary and web-based media hub". ${ }^{29}$

Between May and October 2009, the committee embarked on a series of interviews with former singers, dancers, administrators, journalists and, where needed, their family members. The process of finding interviewees, however, began before the book committee was put together with my efforts to make contact with individual Eoan members via telephone. These conversations were often characterised by concerns voiced by former members who needed to be convinced of Stellenbosch University's commitment to the preservation of the cultural heritage of the group, and questions on why the archive was not transferred to the University of the Western Cape or the University of Cape Town, universities that historically had much closer ties with the group. During the first round of meetings held in the course of 2008, community members were also requested to make themselves available for

${ }^{29}$ US, DOMUS, Eoan Group Archive, Group Book Project, Consent Form, dated 2009. 
interviewing and through persistent phoning, talking and asking for more names and numbers, the list grew as news about the proposed book spread amongst the Eoan community. Furthermore, the book committee decided not only to interview prominent Eoan artists, but also those who stood on the periphery. These were people who witnessed the group's performances and those who had watched the group's gradual descent into political compromise and rejection by their own community. By April 2009 the list reached close to 50 individuals.

During the time of interviewing, the committee met regularly to discuss progress and problems, to reflect on the challenges and make adjustments. In reportbacks by committee members it became clear that "insiders" such as Ruth Fourie, Wayne Muller or Phillip Swales were at times able to elicit much more productive material from interviewees. The complexity of the interview process was illustrated in numerous instances where previous friendships existed or where the power balance between interviewer and respondent was offset by racial categories created and enforced by the apartheid system. Stephanus Muller, for instance, reported that his interview with Prof. van der Ross, former chancellor of the University of the Western Cape and former chairperson of the Eoan Group Trust, resulted in a series of statements Van der Ross thought a white man such as Muller would want to hear.

The opposite became apparent when Ruth Fourie conducted an interview with principal soprano Ruth Goodwin. Their friendship and shared history of more than sixty years produced the most poignant statements, this in contrast to the provocative and defensive tone Goodwin took towards me whenever I telephoned her to arrange a meeting. In Wayne Muller's interview with Gerald Samaai, which is extensively quoted in the book due to its wealth of insightful and poignant material, Wayne addressed Samaai in the colloquial manner of "oom" (Afrikaans for uncle) and in this familial atmosphere Samaai's honesty about, amongst other things, the consequences of the political compromise the group made, became one of many treasured quotes in the Eoan Group Archive. During December 2009, the recorded interviews were digitally copied and given to students who then began the long and time-intensive process of transcribing them. Eventually, more than seventy-five hours of audio-material was transcribed into a body of approximately 200000 words.

At the committee's meeting of 25 February 2010 it was decided that enough interviews had taken place for the book project to go ahead. Although new names of potential interviewees continued to crop up, the committee decided that continuing with these was more properly the future responsibility of DOMUS and that priority now had to be given to shaping the book from the material that had already been collected. The transcripts of the interviews were divided between the members of the committee with the instruction that they should methodically flag passages as they pertained to the themes according to which the interviews had been structured. After this exercise, I was asked to organise all selected material by theme.

This process took some months to complete and on 6 October 2010 the committee met again to decide on the way forward. This was a seminal meeting 
because we were now at a stage where editorial decisions needed to be made and a robust discussion followed on how to create a narrative from the material and who would undertake this task. Stephanus Muller, for instance, suggested we pass the material on to an academic or creative writer outside the book committee. After much debate this suggestion was put aside because the committee felt that the "heartbeat" of the project (as Ronnie Samaai put it) would be lost if the construction of the narrative were to pass from the committee to an outside agency, illustrating yet again, the reluctance to relinquish ownership of the material to an outsider. After much discussion it was then decided that instead, two members of the committee, myself and Wayne Muller, would be given the task to select and arrange a pilot chapter for the book from the selected and organised passages that had emerged from the process. Our task was to select passages we felt were relevant, arrange them in an order to our preference and write a narrative to weave the quotes into a cohesive story. At a subsequent meeting the pilot chapter was discussed and after a number of tweaks, was judged a success. Wayne and I were then asked to follow the same modus operandi in putting together the other chapters of the book.

In the course of the following six months, the book chapters, timeline and appendices Wayne and I had compiled were read, discussed, commented upon and eventually approved by the committee. These discussions were at times difficult and uncomfortable because committee members had opposing ideas on, for instance, how much space and what kind of quotes should be used on the group's leader, Joseph Manca, a man whose reputation with interviewees ranged from adoration to vilification. For many, Manca had made life as an opera singer or chorister a reality; for others, he was an amateur musician whose limited musical talents represented the glass ceiling of inferior standards that were deemed good enough for South Africans who were not white.

Another point of contention was which incidents of South Africa's political history should accompany the timeline in the back of the book that provides an overview of the group's history. Wayne reminded us that even today, the popular facts on South Africa's history under apartheid as portrayed by historians continues to omit the history of the coloured people, a fact I completely missed when I compiled that appendix in the course of 2009. Another concern was the issue of being comprehensive or "including all the facts" of Eoan's history. Academics may be used to the idea that it is impossible to be entirely comprehensive and that what constitutes "all" the facts is entirely subjective; it varies in degree from one individual to another. It soon became clear that such a notion was not shared by all in the committee and it took quite some discussion and convincing before these concerns were addressed and the fear of presenting "incomplete information" was dealt with, even if only superficially. In this regard it is important to note that during its 80-year history, the organisation offered many other activities, such as ballet; drama; ballroom dancing; elocution; literacy classes; and after-care centres for children, activities that in reality have a longer history with the group than opera. Yet, indicative of the interests of a discipline that continues to foreground music, the book focuses predominantly on opera production. The reception of the book by the Eoan 
community also indicated that the lack of focus on the group's history prior to and after its opera production years, as well as the more cursory attention given to the many other activities of the group, were seen as a "shortcoming" of the project.

Institutional and personal concerns at times also had to be set aside in order to honour the goal of allowing the Eoan community's voice to be heard. I will briefly discuss two instances where this came into play. The first concerned the use of grammatically correct English in the quotes by interviewees. Quite early in the process the committee decided that the spoken words of interviewees would be used verbatim, irrespective of grammatically correct utterances or not. Concerns were raised that this may portray some group members as "uneducated" or "confused" or may even give the impression that the book was not properly edited. Yet grammatical constructions that do not necessarily abide with academic decorum are entrenched in Cape Flats' colloquial speech and are part of the social and personal identities that needed to be kept intact.

Another important issue was the discussion on who was to be mentioned as author/s of the book. For most committee members the personal input into the production was huge and relinquishing the recognition inherent to having one's surname on the cover of the book was no easy choice to make. Furthermore, Stellenbosch University had invested in the project by funding the preliminary sorting of the archive as well as various other parts of the project that were cost intensive; not to mention the academics on the university's staff, who were involved in the project and wanted to receive due recognition. Here too, we had a prolonged discussion during which it was agreed that personal and institutional interests had to be set aside. The author of the book became the Eoan History Project. Overall, there were many such discussions of varying degrees of importance that shaped the outcome of the project as a whole and which cannot all be named here. However, the underlying motive and methods of community interaction - that of learning from each other and contributing reciprocally to that process - took place at almost every meeting.

Referring back to the discussion on methodologies applicable to music historiography in the beginning of this article, a number of conclusions can be drawn. With regard to the autonomy debate the themes and questions that were framed before the interviewing process got under way, clearly point towards situating a history of opera performance that preferences contextual factors above that of the work as an autonomous entity. The book therefore does not focus on the music that was performed or the way singers interacted with the music as text, yet it does open up the space on how the group's performances, of for instance Verdi's La Traviata, contributed towards the meaning of the work itself. The focus has been on what opera as a format meant to a particular community in a particular time and social setting.

Another obvious benefit of the chosen methodology is the acknowledgement of subjective experience as legitimate music historiography. The subjectivity of 
human experience and the relativity of "truth" has been well documented and applied to historiography. It ties in with Hobsbawm's statement that "[t]he past we study is only a construct of our minds". ${ }^{30}$ Although these trends have been prevalent for quite a while in historiography in South Africa, in historical writings on Western classical music they far are less commonplace. Through oral history, multiple accounts of events as well as contrasting opinions could be juxtaposed. The diverse ways in which, for instance, apartheid was experienced by people who took part in the same opera production on the same date, at the same venue and directed by the same person, is well illustrated in this book. Hobsbawm, however, also points out that relativism has its limits and states that when it comes to whether certain events happened or not, "few relativists have the courage of their conviction". ${ }^{31}$ Postmodernism seems to have denigrated the idea of subjectivity to the point of "a loss of self" and oral history theorists such as Allessandro Poritelli and Lynn Abrams have both argued for oral history as "reconstruction of selfhood through dialogue". 32 Abrams also argues that oral history does not abscond from its responsibility towards traditional historical research and that "facts" from the seemingly unstable sources of memory can be crosschecked and referenced. ${ }^{33}$ The book therefore incorporates a skeleton timeline, dating certain important happenings in the performance trajectory of the group over time as sourced from written documentation in the Eoan Group Archive.

The foregrounding of language and the position of the author were aims of this project that have been well served by the methodologies of both oral history and the idea of relativism. This allowed for alternating registers of speech that demonstrate the specific use of language by individuals that are part of this specific community. The book contains significant sections in Afrikaans ${ }^{34}$ since that language is the mother tongue of many of the interviewees, yet the choice of language during interviews was predominantly English. This may be attributed to various reasons, representing an intricate web of power relations and perceptions of social standing. It became clear that although Eoan members often spoke Afrikaans amongst themselves, English was the language used by Eoan's management and somehow this translated into respondents speaking predominantly English to those who conducted the interviews. Some respondents (see for example quotes by Ronnie Theys) also chose to use what has recently been coined 'Afrikaaps', a version of the Afrikaans language particular to the Cape Flats. During an informal discussion on Eoan - Our Story, a journalist who reviewed the book for Die Burger, mentioned that for this reason the book is of interest for linguists too. ${ }^{35}$ The characters of individuals have been allowed to come to life in the book, and as one reads the text one cannot but gain a sense that "this is really how it was", while one is continually aware of the

\footnotetext{
${ }^{30}$ Hobsbawm, On History, p viii.

${ }^{31}$ Hobsbawm, On History, p viii.

32 L. Abrams, Oral History Theory (Routledge, London, 2010).

${ }^{33}$ Abrams, Oral History Theory.

${ }^{34}$ English translations have been provided.

${ }^{35}$ Kirby van der Merwe, in private discussion with the author in January 2013. See also his article, "Eoan, die Daeraad en Ondergang”, Die Burger, 26 January 2013, pp 6-7.
} 
subjective nature of such opinions. In this regard, the book concurs with Paul Thompson's words that oral history "can give back to the people who made and experienced history, through their own words, a central place [in history]" ${ }^{36}$

From the perspective of an academic who is used to top-down decision making, perhaps the more challenging method applied in this publication was constructing the text itself through community participation. One part of this is the idea that a democratic process was playing itself out; all participants had an equal say in how the book should be made, yet books have been made by groups of people in the past. What sets community interaction apart as a method lies in the idea of reciprocal learning, as well as an attempt towards the levelling of the power relations between academics and those outside the academe. The powerful positions that the custodians of knowledge hold may not be consciously experienced by academics themselves, but for non-academics, especially those who grew up in disempowered social and cultural groupings during apartheid, the imbalances are huge. Juggling an awareness of such imbalances with, for instance, notions on the relativity of "facts" and "truth" that have been prevalent in the academe but not necessarily in nonacademic environments, was a real challenge for the book committee.

When we began this project in 2008, we had no idea if producing a book by a committee comprising academics and community members was even remotely possible, and if so, how such a process would unfold. There are of course a number of reasons why it did work, perhaps the most important of which was an exceptional team, committed to realising this book project. Each committee member brought with him/her a unique knowledge and worldview. The baggage of a traumatic past carried by each member could easily have derailed the project, but instead it enriched the process in unforeseen and powerful ways. Whether this project was successful in destabilising the power relationships that exist between the academe and the community, will be left for the reader to decide. A first of its kind, it serves to illustrate the vast potential and responsibility of South African music scholars to tell the stories of our country's varied musics in responsible and committed ways, working alongside communities to produce knowledge and history.

\footnotetext{
36 Thompson, "The Voice of the Past", p 25.
} 